\title{
Aeschynomene spp. Identification and Weed Management in Rice Fields in Southern Brazil
}

\author{
Matheus B. Martins ${ }^{1,2, * \mathbb{D}}$, Dirceu Agostinetto ${ }^{1} \mathbb{D}$, Silvia Fogliatto ${ }^{3} \mathbb{D}$, Francesco Vidotto ${ }^{3}$ and André Andres ${ }^{2}$ \\ 1 Plant Protection Department (DFs), Federal University of Pelotas (UFPel), Pelotas 96010-610, Brazil; \\ agostinetto.d@gmail.com \\ 2 Brazilian Agricultural Research Corporation, Pelotas 96010-971, Brazil; andre.andres@embrapa.br \\ 3 Department of Agricultural, Forest and Food Sciences, University of Turin, 10095 Grugliasco, Italy; \\ silvia.fogliatto@unito.it (S.F.); francesco.vidotto@unito.it (F.V.) \\ * Correspondence: matheusbastosmartins@gmail.com; Tel.: +55-12-98260-0026
}

Citation: Martins, M.B.; Agostinetto, D.; Fogliatto, S.; Vidotto, F.; Andres, A. Aeschynomene spp. Identification and Weed Management in Rice Fields in Southern Brazil. Agronomy 2021, 11, 453. https://doi.org/10.3390/ agronomy 11030453

Academic Editor: David Clements

Received: 14 January 2021

Accepted: 25 February 2021

Published: 28 February 2021

Publisher's Note: MDPI stays neutral with regard to jurisdictional claims in published maps and institutional affiliations.

Copyright: (c) 2021 by the authors. Licensee MDPI, Basel, Switzerland. This article is an open access article distributed under the terms and conditions of the Creative Commons Attribution (CC BY) license (https:/ / creativecommons.org/licenses/by/ $4.0 /)$.
Abstract: In 2002, a survey carried out in rice paddies in the Rio Grande do Sul (RS) state reported the occurrence of nine species of jointvetch (Aeschynomene). Due to their semi-aquatic habit, some species adapted to irrigated rice fields, which led to their being considered the worst broadleaf weed in RS. Although farmers have successfully implemented weed management practices, Aeschynomene plants have reportedly escaped chemical control. This study aims to identify the species of Aeschynomene that occur in rice fields in RS and to evaluate the reasons why escapes are occurring. A survey was carried out by collecting mature seeds from individual adult plants. A questionnaire on the management practices employed in each field was administered to 54 farmers and 18 extension agents, each of whom was responsible for one of the surveyed rice fields. This survey found four species of Aeschynomene are present in rice fields in RS: A. denticulata, A. indica, A. rudis, and A. sensitiva. The results suggest that the explanation for escapes may lie in the management practices adopted by farmers, which are focused on the control of weedy grasses. Escapes are also associated with problems such as the lack of irrigation uniformity and out-of-stage, late herbicide applications.

Keywords: jointvetch; lowlands; species identification; survey

\section{Introduction}

The plant genus Aeschynomene (Fabaceae, Papilionoideae) is composed of approximately 180 species, of which 84 are distributed through the American continent and 49 occur in Brazil [1,2]. These plants are herbaceous annuals that develop as small to true bushes with peltate stipules, papilionaceous flowers, and articulate loments united by septa [3]. In 2002, a previous survey carried out in the Rio Grande do Sul (RS) state, the southernmost state of Brazil, reported the presence of nine species belonging to this genus: A. denticulata, A. elegans, A. falcata, A. fructipendulata, A. histrix, A. indica, A. montevidensis, $A$. selloi, and $A$. sensitiva, which are regionally known as "angiquinho" in Brazilian Portuguese and jointvetch in English [4].

Due to its semi-aquatic habit, some jointvetch species are well-suited to the conditions of irrigated rice cultivation, to the point that they are the crop's main broadleaf weed and the third most likely to escape chemical control, behind only weedy-rice and species of Echinochloa [5]. Despite not germinating under flooded conditions [6,7], once established, this weed affects crop productivity by competing for resources, as well as indirectly by hampering harvest operations and diminishing grain and seed quality [8-11].

Differentiating between species of Aeschynomene in rice paddies is extremely difficult. This is due to the similarity of morphological characteristics between the species and because no survey has been carried out to date concerning the occurrence and description of Aeschynomene in rice fields. 
Irrigated rice is widely cultivated in the lowlands of the southern region of RS. Due to the high suitability of the region's soil and climate conditions, farmers are able to grow rice year after year, generally rotated with livestock during the winter [12]. Around $70 \%$ of the state's rice is cultivated under minimum-tillage practices, with low soil movement, though other seeding methods, including conventional, no-tillage, and water-seeded systems, are also common [13]. The Clearfield ${ }^{\circledR}$ technology for weed control is extensively used in irrigated rice, being present in $87 \%$ of the fields, mainly because of the wide spectrum of weeds controlled [14,15]. However, due to the emergence of several imidazolinoneresistant species, farmers have been forced to adopt resistance management practices such as crop rotations, cultivation of winter cover crops, rotating herbicides, and herbicide mixtures with different modes of action $[16,17]$. Though some farmers have successfully implemented these practices, professionals involved in rice production have reported the escape of Aeschynomene plants from their fields, therefore leading to uncertainty regarding which species are, in fact, becoming more problematic. It is important to mention that biotypes resistant to ALS inhibitors and synthetic auxins, the main herbicides used to control jointvetch, have not been reported so far in Brazil.

The objective of this study was to identify species of Aeschynomene in rice fields in RS, to verify their distribution in rice production zones, and to find relationships between the agronomic practices and the presence of the different Aeschynomene species.

\section{Materials and Methods}

\subsection{Aeschynomene spp. Identification and Distribution in Rice Fields in the Rio Grande do Sul (RS) State}

To identify the species of Aeschynomene that occur in rice fields in RS, mature seeds were collected from adult plants that escaped weed control measures during the ricegrowing season. The seeds that made up each sample were collected from five adult plants in each surveyed field, which had their geographic coordinates recorded using a global positioning system (GPS) equipment. Seeds were collected between February and April 2019. Collections were carried out in the three municipalities with the highest rice yield in the previous cropping season, in each of the six rice-producing regions of RS (Campanha, Central Region, External and Internal Coastal Plains, Southern Zone, and Western Border, indicated with different colors in Figure 1, while the municipalities included are identified with a number on the map), according to the survey conducted by the Rio-Grandense Rice Institute (IRGA) [18]. In each municipality, we scouted three rice paddies with a reported jointvetch escape problem, totaling 54 fields, and identified five adult plants in each paddy site using morphological keys [3,4]. We sampled their seeds, which were packed in individual paper bags and identified with a unique code, totaling 270 samples.

The main morphological characteristics used to identify these species in the field are listed in Table 1. The characteristics that distinguish A. denticulata from the other species are its serrated leaflet margins, branches and stem densely covered by trichomes, yelloworangish flowers, and parallel loment margins (Table 1, Figure A1). Furthermore, all the structures that are covered with trichomes release a kind of wax, which easily adheres to hands and gives off an unpleasant smell.

Table 1. Morphological characteristics used to distinguish Aeschynomene species at rice fields.

\begin{tabular}{ccccc}
\hline Characteristic & A. denticulata & A. indica & A. rudis & A. sensitiva \\
\hline Leaflets & Serrated & Entire & Entire & Entire \\
Touch sensibility & No & No & No & Ges \\
Branches & Densely trichomatous & Glabrous & Sparse trichomes & Glabrous \\
Stem & Densely trichomatous & Glabrous & Sparse trichomes & Glabrous \\
Flower color & Yellow-orangish & Yellow-whitish & Yellow-orangish & Yellow \\
Loments & Parallel margins & Sinuous bottom margin & Sinuous bottom margin & Sinuous bottom margin \\
Articles & Velvety & Rough & Ridged & Compressed \\
\hline
\end{tabular}

\footnotetext{
1: After a slight touch of the petiole, the leaflets are induced to close toward the leaf center. Adapted from $[3,4,7]$
} 


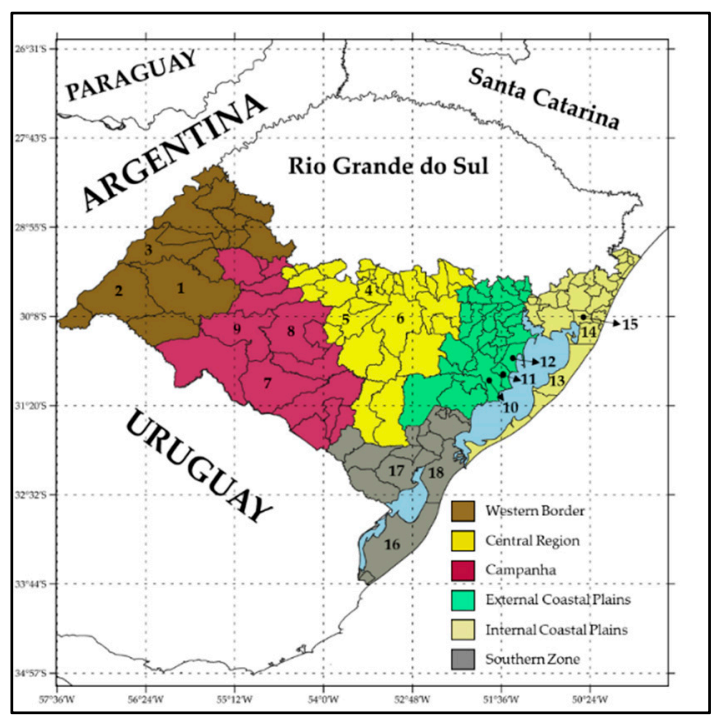

Figure 1. Municipalities visited for seed sampling of Aeschynomene spp.: 1-Alegrete, 2-Uruguaiana, 3-Itaqui, 4-Restinga Seca, 5-São Sepé, 6-Cachoeira do Sul, 7-Dom Pedrito, 8-São Gabriel, 9-Rosário do Sul, 10-Camaquã, 11-Arambaré, 12-Tapes, 13-Mostardas, 14-Palmares do Sul, 15-Viamão, 16-Santa Vitória do Palmar, 17-Arroio Grande, and 18-Rio Grande.

Aeschynomene indica distinguishes itself from other species most visibly by the coloring of its flowers, which are yellow-whitish, and by the presence of loments with sinuous bottom margin and articles with a rough surface (Table 1, Figure A2). During its vegetative growth stages, this species is very similar to $A$. sensitiva since both have entire leaflet margins and glabrous branches and stem. One of the few vegetative features that differentiate the two species is sensitivity to touch, present in the leaves of $A$. sensitiva, which close at a slight touch to the petiole, whereas those of $A$. indica do not. Another distinctive vegetative characteristic is the plentiful ramification produced by $A$. indica, which starts at the stem base, while $A$. sensitiva exhibits an intense vertical growth, reaching up to four meters high, with few branches at the top of the stem with small vivid yellow flowers. Finally, the stem of $A$. sensitiva is considerably thicker and acquires a dark-brownish color at the base (Table 1, Figure A3).

The characteristics that enable $A$. rudis to be differentiated from other species of the genus are its entire leaflet margins, which are also observed in A. indica and A. sensitiva, while its branches and stem are covered with sparse trichomes, which are longer and stiffer than those found on $A$. denticulata. Its flowers are yellow-orangish, exhibiting a distinct red trace on the petals. The loments of $A$. rudis also have a sinuous bottom margin and articles with a ridged surface due to the presence of several protrusions (Table 1, Figure A4).

After collection, the seeds were dried, cleaned, and stored for two weeks in a fridge $\left(7^{\circ} \mathrm{C}\right)$ and then in a cold chamber, with a stable temperature of $17^{\circ} \mathrm{C}$. This procedure was performed to control stored-product insects that might damage the seeds, making them unfeasible for use during the subsequent steps of this study.

During the spring and summer of 2019, five seeds from each sample were sown after their article was removed, and they were mechanically scarified using 180 grit sandpaper. To standardize the strength applied over the seeds in this process, a cup filled with $750 \mathrm{~g}$ of sand was settled over the sandpapers, and then the whole apparatus was turned around its center twice. At least one plant from each sample was grown in a greenhouse in $10 \mathrm{~L}$ buckets filled with $8 \mathrm{~kg}$ of soil. The morphological characteristics were then photographically recorded to illustrate the characteristics that were used for identification in the field and to determine additional features that would allow an easier differentiation between the species. 


\subsection{Weed Management Overview}

Immediately during or right after seed collection in the field, the 54 farmers and 18 extension agents responsible for each rice field answered questions about the management practices used on the sampled areas, relating them to the presence of Aeschynomene. Farmers were asked about the time of continuous rice cultivation, the main cultivation method on the farm (type of tillage and sowing), the level of adoption of Clearfield ${ }^{\circledR}$ technology, the number of herbicide applications in a season, the adoption of the "needle-point" burndown technique [19], specific practices to manage resistant weeds, and which herbicides were sprayed at pre- and post-emergence. Extension agents were asked about their opinion on the escape and presence of Aeschynomene plants in the fields.

\subsection{Statistical Analysis}

The results were analyzed using descriptive statistics and the values presented as percentages.

A multinomial logistic regression was performed to ascertain the effects of some agronomic practices (independent variables) on the likelihood of finding the different Aeschynomene species (A. denticulata, A. indica, and A. rudis) (categorical dependent variable) on the surveyed area. Aeschynomene sensitiva was excluded from the analysis as it was only found in a single field.

The agronomic practices considered were: continuous time of rice cultivation, number of herbicide applications through the growing season, predominant cultivation system with three levels (conventional tillage, minimum tillage, and water seeding), use of crop rotations (yes, no), use of winter cover crops (yes, no), use of herbicide mixtures (yes no), use of rotation of herbicides with different mode of action (yes, no), use of increased herbicides doses (yes, no), absence of weed management (yes, no), use of the needlepoint burndown application (yes, no). All the independent variables were categorical dichotomous or polytomous (management) and were considered as a factor in the analysis, except for number of herbicide applications and continuous time of rice cultivation, which were continuous.

The model was run initially with all the abovementioned variables and then the model was re-run with only the variables that were significant in the previous analysis for at least one of the species. The non-significant discarded final variables were continuous time of rice cultivation, use of crop rotation, and the needle-point burndown. Independent variables were considered significant at $p \leq 0.05$. The reference category of the dependent variable was the species $A$. denticulata.

The analysis was conducted by using the multinom function of the package nnet of the statistical program R [20].

\section{Results}

\subsection{Aeschynomene spp. Identification and Distribution in Rice Fields in RS}

Figure 2 displays as black dots the locations of the fields in which Aeschynomene plants were identified. Of the 270 Aeschynomene samples, 161 were identified as $A$. denticulata (59.6\%), 97 as $A$. indica (35.9\%), nine as A. rudis (3.3\%), and three as $A$. sensitiva (1.1\%), according to keys [3,4].

Aeschynomene denticulata was the only species present in all municipalities visited, as well as the only species found in the rice fields surveyed in the Western Border (Figure 2a). In the other rice production zones, a higher diversity of Aeschynomene species was found, though $A$. denticulata predominated in the Central Region and Campanha as well. The predominant species in the Internal and External Coastal Plains was A. indica (Figure 2b).

There was a high variability of Aeschynomene species in the External Coastal Plains and Southern Zone, especially in the municipalities of Viamão and Arroio Grande, where three species (A. denticulata, $A$. indica, and $A$. rudis) were found in a single rice field. This paper represents the first verified report of $A$. rudis at rice fields in RS (Figure 2c). This species is frequently mistaken for $A$. denticulata, with which it shares certain similarities, as 
well as with $A$. virginica, an endangered species that only occurs in a restricted area of the United States of America [8,21].

The only production zone in which $A$. sensitiva occurred was the Central Region, in the city of Restinga Seca, in a field cultivated under the water-seeded system. No herbicide was sprayed prior to the day that it was found (Figure $2 \mathrm{~d}$ ).

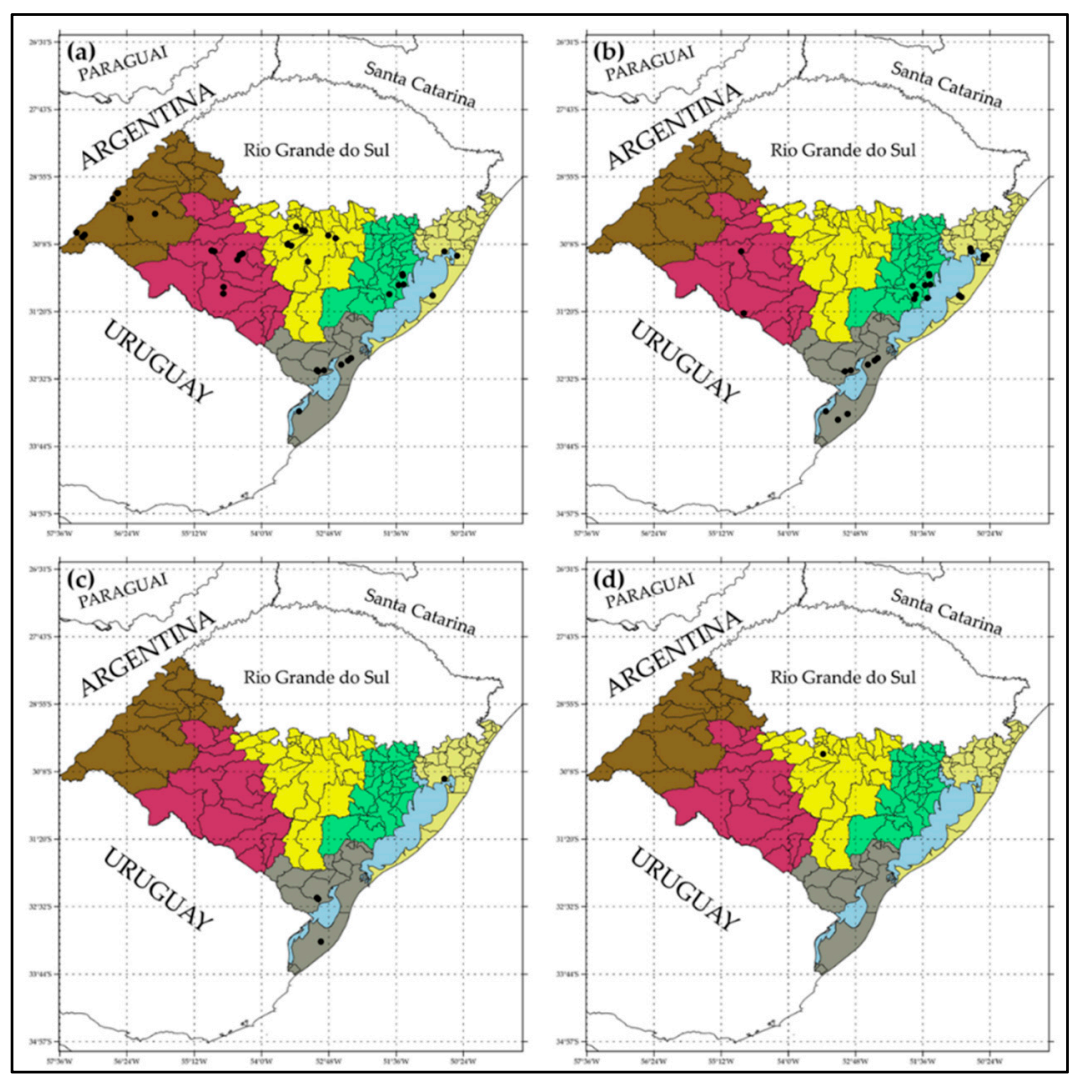

Figure 2. Geographic coordinates of rice fields where at least one plant of (a) A. denticulata, (b) A. indica, (c) A. rudis, and (d) A. sensitiva were found.

\subsection{Weed Management Overview}

The results from the questionnaires administered to farmers and extension agents provide an overview of the current context of the weed and crop management practices adopted in rice production systems in RS. Of the fields surveyed, $18 \%$ had been cultivated with rice for ten consecutive years, and 30\% had been cultivated for more than five consecutive years (Figure 3a). Meanwhile, 30\% had only been cultivated for two consecutive years, and $22 \%$ were first-year rice fields (which had just come from a fallow period or which had been cultivated with other crops). Rotation with other crops aims to reduce the weed seedbank in the soil since the continuous cultivation of rice, year after year, creates favorable conditions for a wide range of species to persist [22,23].

Over half of the rice fields (51\%) used minimum tillage (Figure $3 b)$. There are certain advantages to this method, including minimal soil turnover, which reduces the cost of tillage operations and allows rice seeding to be carried out during the most favorable period. Minimum tillage also facilitates the use of pre-emergence weed control, ensuring reduced infestation of weeds during the critical establishment stages of the crop [24,25]. Another $38 \%$ of the rice fields surveyed still use conventional tillage (several plow and harrow operations), which aims to eliminate weeds that have already emerged mechanically and to level the soil. A small percentage of the surveyed fields $(11 \%)$ were planted using a water-seeded system, in which cultivated areas are kept flooded during the winter, and tillage is carried out in wet soil [26]. 


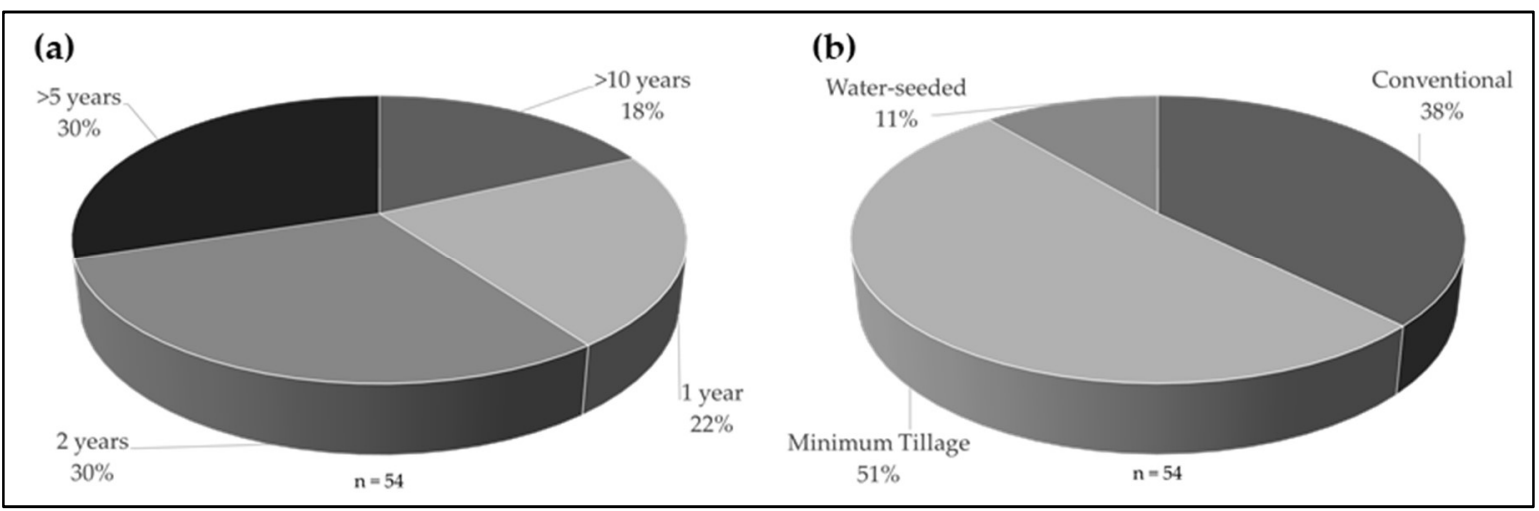

Figure 3. (a) Continuous time of rice cultivation and (b) predominant cultivation system at rice fields in which Aeschynomene seeds were sampled. In (a), no field was continuously cultivated with rice for 3 or 4 consecutive years.

Clearfield ${ }^{\circledR}$ technology (CL) was introduced in RS in the 2003-2004 growing season, marketed as the first imidazolinone-resistant rice variety for use with herbicides to control weedy-rice [27,28]. CL rice was used in $87 \%$ of the rice fields surveyed, which demonstrates the importance of the technology, even despite the wide distribution of ALS-resistant weed species in rice fields in southern Brazil [29,30].

One method used by rice farmers to manage hard-to-control weeds is a burndown application using a non-selective herbicide, usually glyphosate, as soon as the crop reaches the phenological stage S3 (emergence of prophyll from coleoptile), popularly known in RS as a "needle-point" burndown $[19,31]$. This practice was adopted by $72 \%$ of the farmers interviewed. Given that $11 \%$ of the surveyed rice fields used a water-seeded system, in which this method is not practical because the seeds are sown beyond S3, only $17 \%$ of the scouted rice fields do not adopt this practice, highlighting its importance.

Of the farmers surveyed (Figure $4 a$ ), $70 \%$ of them perform weed control measures at least three times during the growing season: a burndown for weeds that emerged before seeding, one pre-emergence, and one post-emergence application of herbicide, the latter of which is applied one or two days before the field is flooded. A lower proportion (6\%) of the farmers perform a fourth herbicide spraying, called late post-emergence, aiming to control weed escapes, while another $24 \%$ of farmers spray herbicides only twice, which can happen at a variety of different moments during the growth season, as a burndown, pre-, early post-, or late post-emergence application.

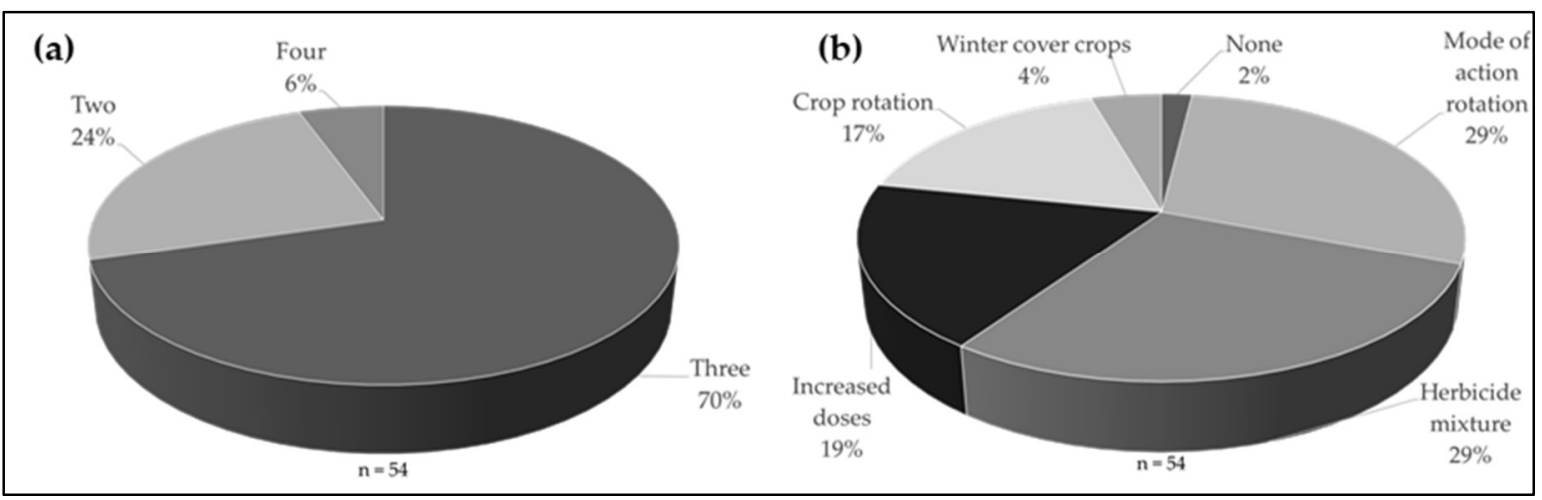

Figure 4. (a) Number of herbicide applications during the rice-growing season and (b) specific practices adopted to manage resistant weeds in surveyed fields in which Aeschynomene seeds were sampled. 
Almost all farmers surveyed (98\%) indicated that they used specific practices to manage herbicide-resistant weedy-rice and barnyardgrass, which can contribute to avoid selecting herbicide-resistant jointvetch biotypes. They adopt at least one or two of the options listed in Figure 5b. The two most frequently mentioned strategies, both of which are adopted in $29 \%$ of the surveyed rice fields, were related to chemical control: rotation of the mode of action and herbicide mixtures. The percentage of farmers that do not rotate modes of action is still high, while another 19\% of farmers use doses that are higher than the label dose (Figure 5b), a practice that increases the overall cost and the selection pressure for resistant weeds [32]. Of the options that do not involve chemical control, only two cultural methods are adopted. Currently, only $17 \%$ of fields use crop rotation, while winter cover crops are grown on just $4 \%$ of the fields surveyed. The benefits of these practices extend beyond integrated weed management, with the potential to reduce disease and pest occurrence, tillage expenses, and soil fertility improvements [33]. However, due to the physical characteristics of soils in which rice is cultivated in RS, farmers must make a number of adjustments to improve the root environment and ensure the viability of rotations with soybean, corn, winter cereals, and livestock-integrated systems. These adjustments include the use of drainage and irrigation systems, land leveling, $\mathrm{pH}$ correction, and soil decompaction [34].

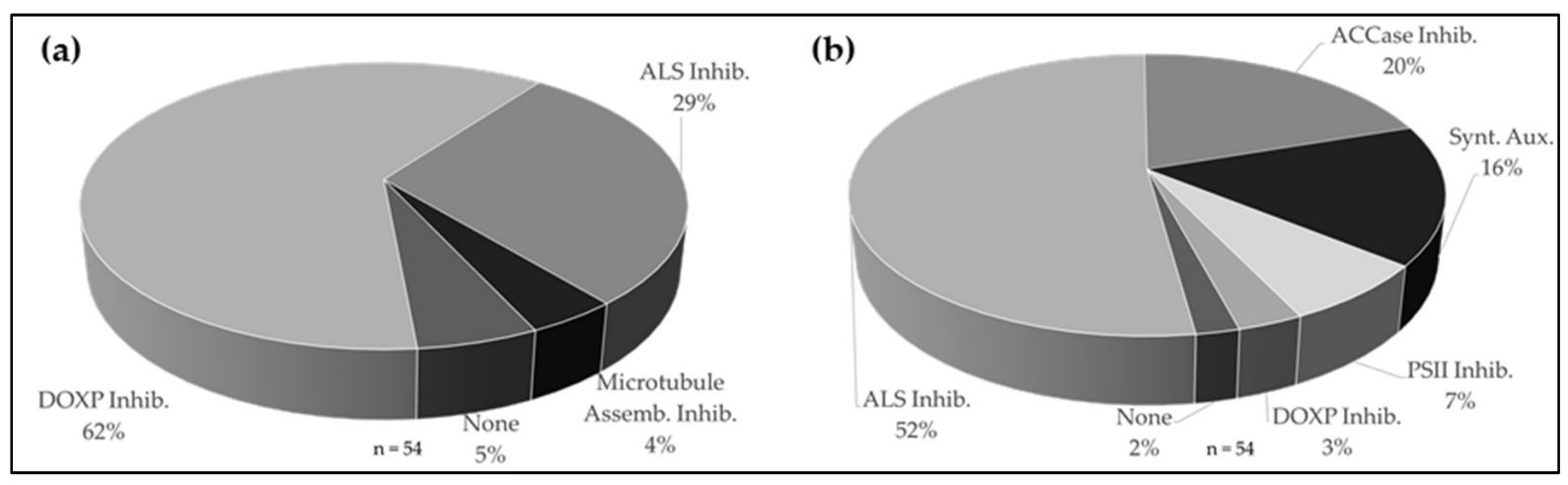

Figure 5. (Percentage of farmers that perform herbicide applications at (a) pre-emergence and (b) post-emergence and the most frequently reported herbicide modes of action used in the rice fields in which Aeschynomene seeds were sampled.

Since chemical control strategies are the most commonly adopted by rice farmers in the surveyed fields, the herbicide program used by each farm was identified to determine the most common options for pre- and post-emergence applications (Figure 5a,b). Only $5 \%$ of the farmers indicated that they did not spray prior to emergence (Figure 5a). Of the farmers who do apply pre-emergence herbicides, $62 \%$ use clomazone, a 1-deoxy-Dxylulose 5-phosphate (DOXP) inhibitor [35]. ALS-inhibiting herbicides are the next most common, with $14 \%$ using imazapyr + imazapic and $1 \%$ using imazethapyr + imazapic, both of which are labeled only for use on Clearfield ${ }^{\circledR}$ varieties. Clomazone and imazapyr + imazapic thus represent $76 \%$ of all pre-emergence herbicide applications, which primarily aim to control Echinochloa species and weedy-rice. The chemical options used to control Aeschynomene species at pre-emergence are penoxsulam (adopted by $4 \%$ of farms) and imazapyr + imazapic since pendimethalin (adopted by 3\% of farms), a microtubule assembling inhibitor, is only effective at controlling grass weeds, and neither imazethapyr alone nor as imazethapyr + imazapic mixture is effective at controlling broadleaf weeds in irrigated rice [36-38]. Thus, when Aeschynomene is present it may be necessary to spray a different herbicide to complement the action of imazapyr + imazapic, especially at advanced development stages, as the species is tolerant to imazapic [39]. 
In most of the rice fields surveyed (98\%), farmers perform at least one post-emergence herbicide application (Figure 5b), of which 52\% use ALS inhibitors. Specifically, by decreasing the order of frequency, farmers use imazapyr + imazapic (25\%), imazethapyr (14\%), penoxsulam (9\%), metsulfuron-methyl (1\%), bispyribac-sodium (1\%), ethoxysulfuron-ethyl $(1 \%)$, and imazethapyr + imazapic (1\%). ACCase-inhibiting herbicides are used by $20 \%$ of the interviewed farmers, with cyhalofop-butyl (17\%) predominating due to its high selectivity toward rice [40]. A small percentage of farmers used fenoxaprop (3\%) against weedy grasses. The synthetic auxins quinclorac and picloram are used by $13 \%$ and $3 \%$ of the interviewed farmers, respectively, as they are effective at controlling Aeschynomene species. The main use of quinclorac is to control Echinochloa species, as it is highly selective to rice [41]. Two photosystem II inhibitors, bentazone and propanil, are used by $6 \%$ and $1 \%$ of the interviewed farmers [42], respectively, to control sedges and Echinochloa species. Clomazone, a DOXP inhibitor, is used at post-emergence by $3 \%$ of the interviewed farmers to obtain an overlay of residual effects.

When asked about the escape of Aeschynomene in the rice fields despite the management practices implemented, $45 \%$ of extension agents mentioned irrigation deficiency as the main problem (Figure 6). This is justified by the spatial clustering of paddies, which makes it challenging to keep the water level stable. In such situations, or when flooding is sub-optimal due to operational problems with generators interrupting water supply, an opportunity exists for a new cohort of Aeschynomene to emerge, a situation in which the weed becomes established and develops until the end of the rice-growing season. Other factors explaining the presence of species of Aeschynomene at the end of the rice-growing season is the low rate of success of late herbicide application specifically devoted to controlling this weed (30\%). Some extension agents also mentioned innate tolerance to herbicides $(12 \%)$ and low label doses $(8 \%)$ as other reasons for Aeschynomene species to be present at the end of the rice-growing season, and a few of them (5\%) suspect that there are already herbicide-resistant biotypes in the rice fields.

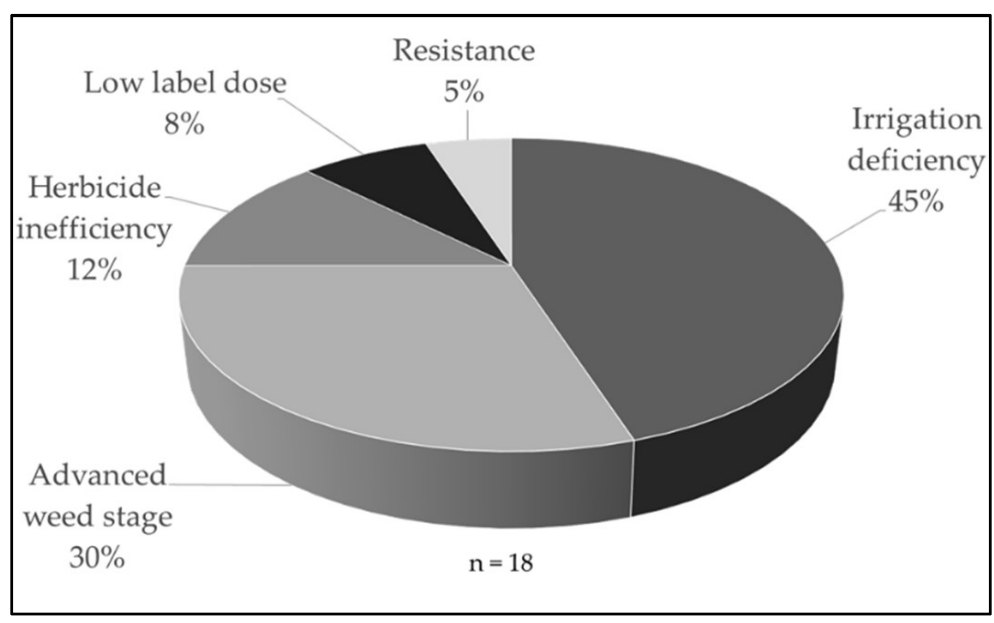

Figure 6. Perception of extension agents regarding the escape and presence of Aeschynomene plants at the rice fields despite the management practices adopted.

The applied model performed to find relationships between the agronomic practices and the presence of a certain Aeschynomene species correctly classified $63 \%$ of cases. 
The confusion matrix highlighted that the model was able to classify correctly about $62 \%$ of the observations of $A$. denticulata and $67 \%$ of $A$. indica (Table 2 ). The model misclassified all the observations related to $A$. rudis, probably because very few observations were present.

Table 2. Classification results after the calculation of confusion matrix for the three Aeschynomene species.

\begin{tabular}{cccc}
\hline Species & $\begin{array}{c}\text { Number of } \\
\text { Observations }\end{array}$ & $\begin{array}{c}\text { Number of Misclassified } \\
\text { Observations }\end{array}$ & Success Rate (\%) \\
\hline A. denticulata & 66 & 41 & $62 \%$ \\
A. indica & 12 & 8 & $67 \%$ \\
A. rudis & 5 & 0 & $0 \%$ \\
\hline
\end{tabular}

In the multinomial logistic regression analysis, by default, the first category of a dichotomous or polytomous variable is used as the reference category and consequently does not appear in the results (Tables 3 and 4). For polytomous variables, the effect of the second and third categories are compared separately with the first category, while for dichotomous variables, the effect of the second category is compared with the first. In our study, the variables and related default reference categories were cultivation system (conventional), use of cover crop (yes), herbicide mixtures (yes), modes of action (MoA) rotation (yes), increased doses (no), and absence of weed management (yes).

The odds ratio highlighted that a higher probability of finding $A$. indica instead of $A$. denticulata (reference species) was associated with water seeding (1.3 times higher for $A$. indica) and with the use of some practices to control weeds $\left(7.66 \times 10^{29}\right.$ times higher for A. indica) (Table 3). On the contrary, the absence of using rotation with herbicides having different modes of action (MoA) rotation increased the probability of finding A. denticulata instead of $A$. indica, as suggested by the negative value of the coefficient (Table 3 ). The same effect, even with a lower degree (0.50 times), was estimated for not using the cover crops.

Table 3. Multinomial logistic regression predicting the likelihood of finding Aeschynomene indica instead of A. denticulata based on different agronomic practices.

\begin{tabular}{|c|c|c|c|c|c|c|}
\hline Variables & Coefficient & $\mathrm{SE}^{1}$ & Wald $(z)$ & $\mathrm{Df}^{2}$ & $p$ & Odds Ratio \\
\hline number of herbicide applications & 0.41 & 0.62 & 0.67 & 1 & 0.501 & 1.52 \\
\hline cultivation system $=$ minimum tillage & 0.26 & 0.59 & 0.44 & 1 & 0.658 & 1.30 \\
\hline cultivation system $=$ water seeding & 84.77 & $2.69 \times 10^{-14}$ & $3.15 \times 10^{15}$ & 1 & 0.000 & $6.55 \times 10^{36}$ \\
\hline cover crops $=$ no & -0.69 & 0.88 & -0.78 & 1 & 0.434 & 0.50 \\
\hline herbicide mixtures $=$ no & 1.63 & 1.33 & 1.23 & 1 & 0.220 & 5.11 \\
\hline MoA rotation ${ }^{3}=$ no & -50.12 & $2.61 \times 10^{-14}$ & -1.92 & 1 & 0.000 & $1.70 \times 10^{-22}$ \\
\hline increased doses $=$ no & 0.46 & 0.59 & 0.78 & 1 & 0.435 & 1.59 \\
\hline absence of weed management $=$ no & 68.81 & 1.12 & 61.29 & 1 & 0.000 & $7.66 \times 10^{29}$ \\
\hline
\end{tabular}

${ }^{1}$ : Standard error. ${ }^{2}$ : degrees of freedom. ${ }^{3}$ : rotation of herbicides with different modes of action.

The probability of finding $A$. rudis instead of $A$. denticulata increased with the number of herbicide applications by $9.73 \times 10^{6}$ times, with the adoption of minimum tillage by $3.40 \times 10^{6}$, if cover crops were not used by $2.71 \times 10^{13}$, if herbicide mixtures were not used by $2.68 \times 10^{9}$, and if increased doses were not used by $5.08 \times 10^{8}$ (Table 4 ). However, the model was not able to correctly classify any of the $A$. rudis observations (Table 2). 
Table 4. Multinomial logistic regression predicting the likelihood of finding Aeschynomene rudis instead of $A$. denticulata based on different agronomic practices.

\begin{tabular}{|c|c|c|c|c|c|c|}
\hline Variables & Coefficient & $\mathrm{SE}^{1}$ & Wald $(z)$ & $d f^{2}$ & $p$ & Odds ratio \\
\hline number of herbicide applications & 16.09 & 0.46 & 34.63 & 1 & 0.000 & $9.73 \times 10^{6}$ \\
\hline cultivation system $=$ minimum tillage & 15.04 & 1.00 & 15.03 & 1 & 0.000 & $3.40 \times 10^{6}$ \\
\hline cultivation system $=$ water seeding & -22.49 & $8.55 \times 10^{-16}$ & $-2.63 \times 10^{16}$ & 1 & 0.000 & $1.71 \times 10^{-10}$ \\
\hline cover crops $=$ no & 30.93 & 0.15 & 199.77 & 1 & 0.000 & $2.71 \times 10^{13}$ \\
\hline herbicide mixtures $=$ no & 21.71 & 0.85 & 25.65 & 1 & 0.000 & $2.68 \times 10^{9}$ \\
\hline MoA rotation ${ }^{3}=$ no & -56.97 & $8.55 \times 10^{-16}$ & $-6.66 \times 10^{16}$ & 1 & 0.000 & $1.81 \times 10^{-25}$ \\
\hline increased doses $=$ no & 20.05 & 0.82 & 24.48 & 1 & 0.000 & $5.08 \times 10^{8}$ \\
\hline absence of weed management $=$ no & -38.49 & 0.15 & -248.48 & 1 & 0.000 & $1.92 \times 10^{-17}$ \\
\hline
\end{tabular}

${ }^{1}$ : Standard error. ${ }^{2}$ : degrees of freedom. ${ }^{3}$ : rotation of herbicides with different modes of action.

\section{Discussion}

This study identified the four following Aeschynomene species in the rice fields surveyed: $A$. denticulata, $A$. indica, $A$. rudis, and $A$. sensitiva. The most common species was $A$. denticulata, found in all the six rice production zones of the state. The wide distribution and predominance of this species in RS has been suggested by other authors [6] and was confirmed in this study. As for A. indica, in addition to being present in the Central Region and Campanha, it is the predominant species in the External and Internal Coastal Plains and the Southern Zone. Reports from previous surveys indicate that this species is primarily distributed in the coastal and central regions of RS, supporting the results of this study [43]. Aeschynomene rudis was only present in the External Coastal Plain and South Zone, while A. sensitiva was observed only in the Central Region. Although this survey was carried out systematically and following a pre-defined methodology, it should be noted that the possibility remains of other Aeschynomene species being present at rice fields in RS. Additionally, the chance cannot be ruled out that the species mentioned in this study may be present in rice production zones where no individuals were found in this survey.

The results from this survey show that there might be other reasons other than germination and establishment of Aeschynomene plants under flooded conditions that explain why escapes occur despite the management practices adopted. Problems in maintaining constant irrigation, either because of land-level or water supply issues, can reduce the effectiveness of management practices and result in moments of high oxygen availability and increased temperature that allow the weed to establish itself and grow. This effect is well documented for other weed species occurring on rice fields [44-46], constituting a major problem for weed management on the crop worldwide; therefore, attention is required to avoid further problems with the Aeschynomene species described in this work.

Another aspect that stands out in the results is that the reliance on chemical control options are not well suited to manage the Aeschynomene species identified. Since most of the herbicides used have the objective to control grass weeds, a broadleaved-weed selection pattern starts to emerge $[47,48]$. Therefore, a change on the chemical options used might be considered, choosing herbicides with a wider control spectrum and, as the multinomial logistic regression results indicated, that the absence of mode of action rotation can be one of the reasons for the predominance of A. denticulata.

More in general, the multinomial logistic regression results may provide useful indications for predicting the effects on the predominance of one Aeschynomene species of the adoption of practices that deserve to be encouraged: for example, the adoption of winter cover crops maintains the soil covered during the whole year, creating an opportunity to no-tillage systems and interfering on early weed establishment during rice growing season [49]. 
Studies are currently being carried out with a focus on the biology and ecophysiology of Aeschynomene spp., aiming to confirm whether its germination and emergence occur under flooded or only dry soil conditions. Other lines of research include studies on seed dormancy and longevity. There are demands for future investigations to examine whether these species display differential herbicide sensitivity, as well as screening populations of these species for herbicide resistance, aiming to manage the resistant biotypes in rice fields in RS.

In an entirely distinct but important field of study, acquiring more in-depth knowledge of these leguminous species may be valuable, such as considering their use to biologically fix nitrogen through symbiosis with bacterial strains [50]. While certainly a challenge, such use of Aeschynomene species might re-engineer its role in the production system. Rather than being a noxious weed, it could be used as effective green manure for hydromorphic soils, helping to increase the sustainability of lowland agricultural systems.

\section{Conclusions}

Four Aeschynomene species were present in rice fields in RS: A. denticulata, A. indica, $A$. rudis, and $A$. sensitiva. The results of this study indicate that the effectiveness of management practices adopted by farmers, focused on grass weed control, are hampered by problems in maintaining stable flooding and late herbicide spraying when weeds are at advanced development stages, which may explain why escapes are occurring. Even though this work was conducted in Brazil, the results can be useful in other countries in which these species are problematic for rice production and where the management practices are similar.

Author Contributions: Conceptualization, M.B.M., D.A. and A.A.; methodology, D.A. and A.A.; validation, M.B.M., S.F. and F.V.; formal analysis, M.B.M., S.F. and F.V.; investigation, M.B.M.; resources, D.A. and A.A.; data curation, M.B.M.; writing—original draft preparation, M.B.M.; writing—review and editing, D.A., S.F., F.V. and A.A.; visualization, M.B.M.; supervision, D.A. and A.A.; project administration, D.A.; funding acquisition, A.A. All authors have read and agreed to the published version of the manuscript.

Funding: This research received no external funding.

Acknowledgments: The authors would like to thank the Cordenação de Aperfeiçoamento de Pessoal de Nivel Superior (CAPES), the Plant Protection Department (DFs), the Federal University of Pelotas (UFPel), and the Brazilian Agricultural Research Corporation (Embrapa Clima Temperado) for the material and support provided. Thanks to the colleagues, interns, and employees of both institutions that made this work possible and a special acknowledgment to the farmers and extension agents that gave some of their time and opened their properties to answer the survey and interviews.

Conflicts of Interest: The authors declare no conflict of interest. 


\section{Appendix A}
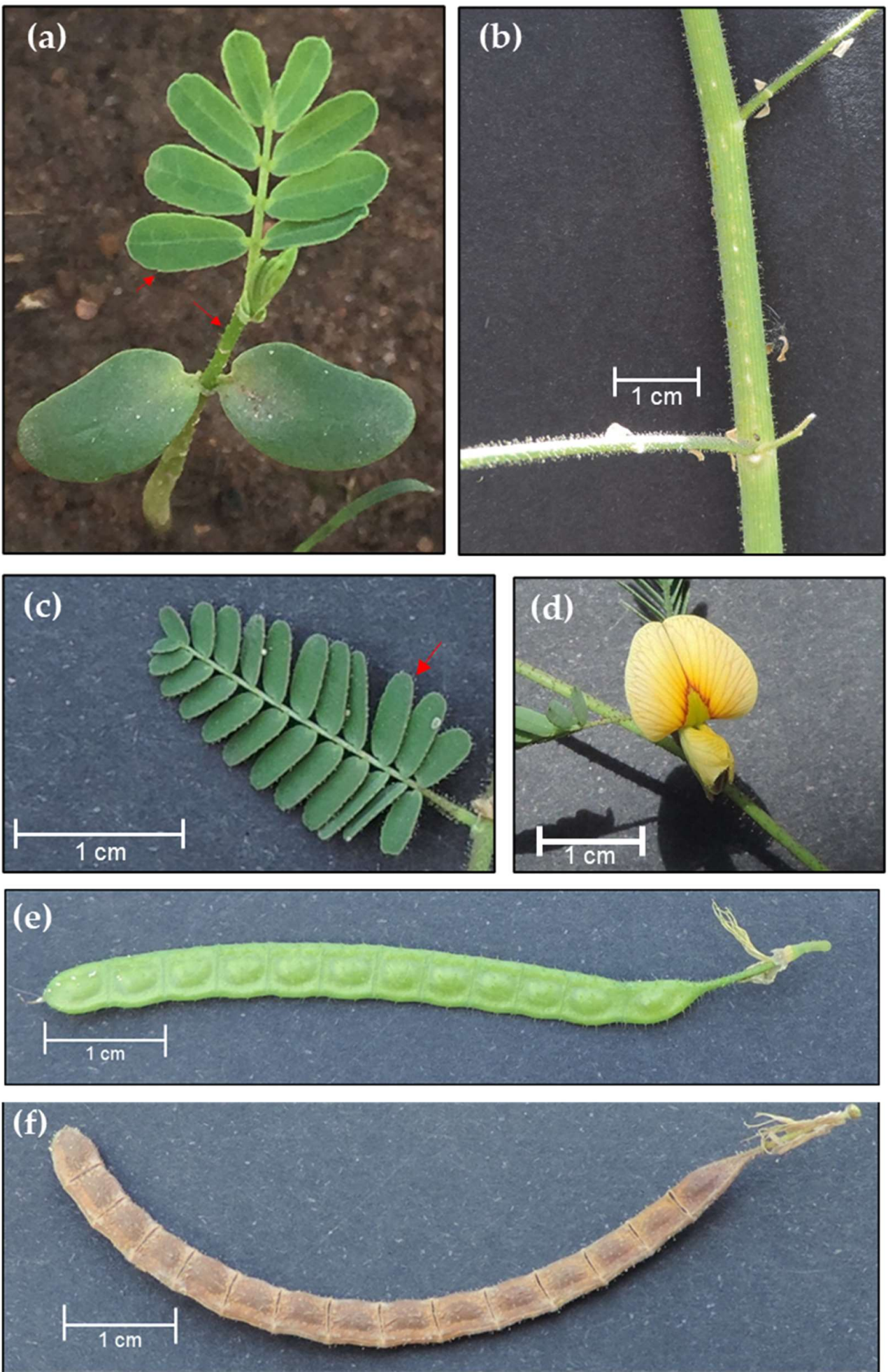

Figure A1. Aeschynomene denticulata. (a) Seedling and detail of serrated leaflet margins and stem covered by trichomes. (b) Branches and stem covered by trichomes. (c) Leaf and detail of serrated leaflet margins. (d) Flower. (e) Ripening and (f) mature loments and articles. 

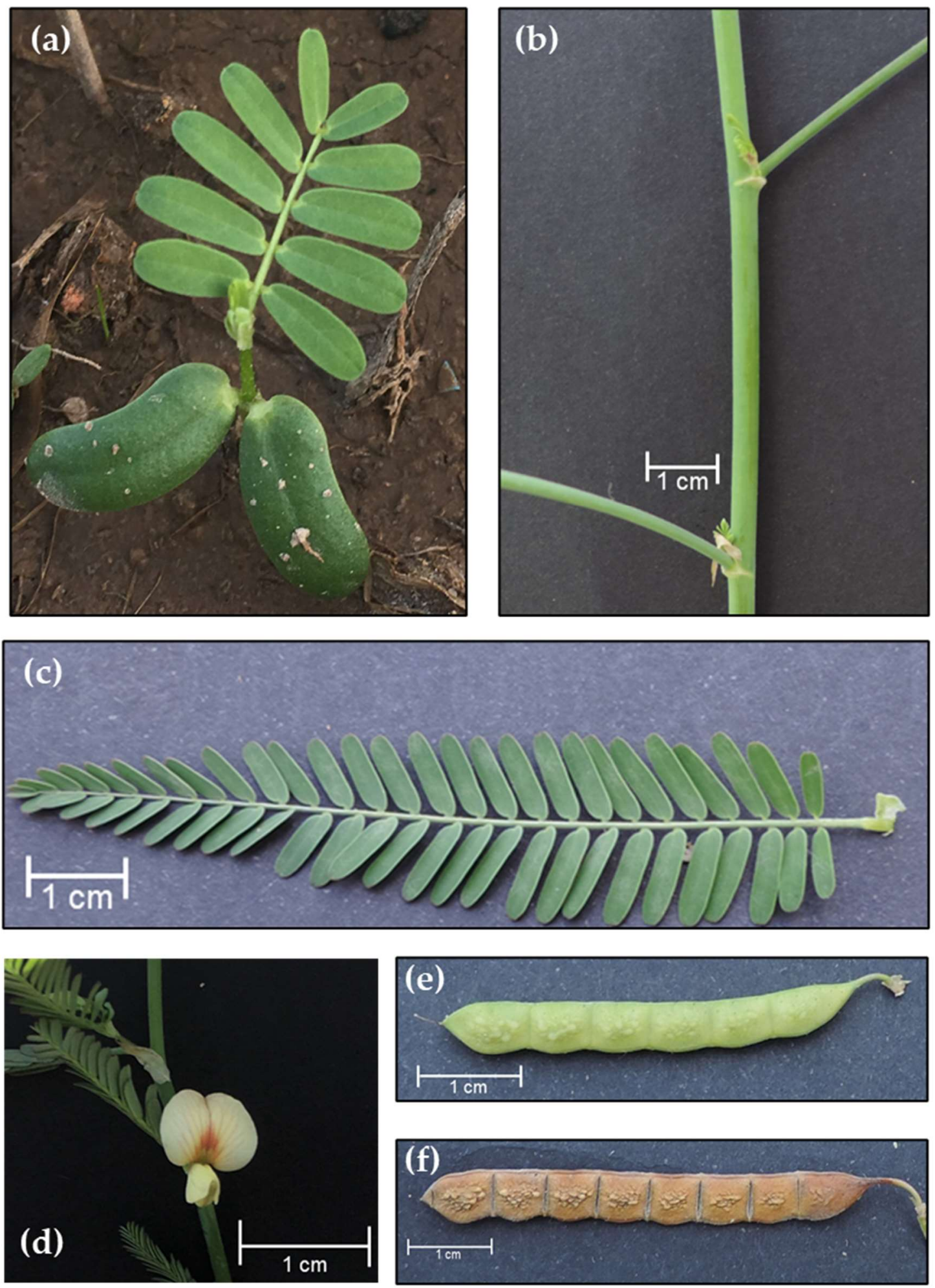

Figure A2. Aeschynomene indica. (a) Seedling. (b) Glabrous branches and stem. (c) Leaf and leaflets with entire margins. (d) Flower. (e) Ripening and (f) mature loments and articles. 

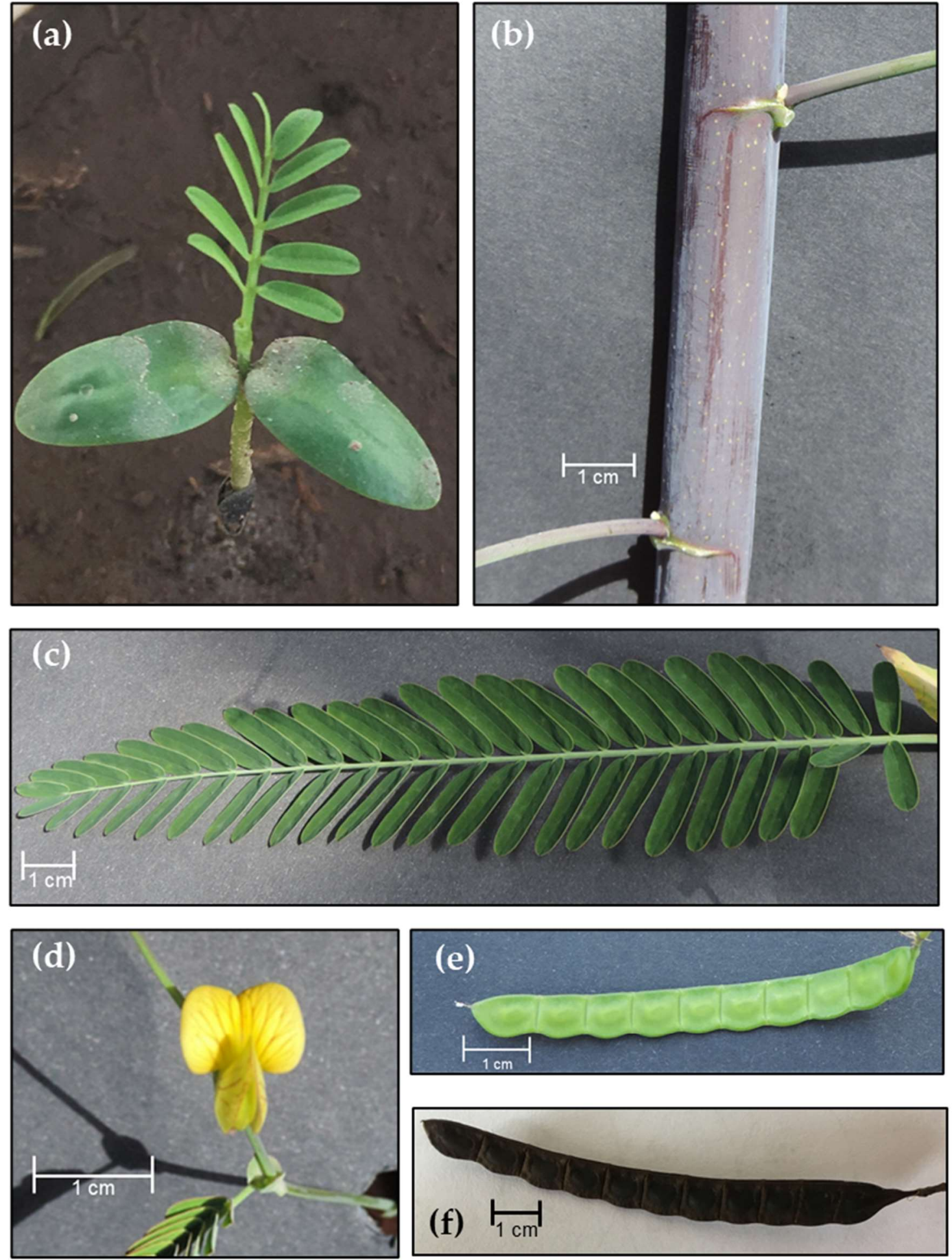

Figure A3. Aeschynomene sensitiva. (a) Seedling. (b) Branches and dark stem, both glabrous. (c) Leaf and leaflets with entire margins. (d) Flower. (e) Ripening and (f) mature loments and articles. 

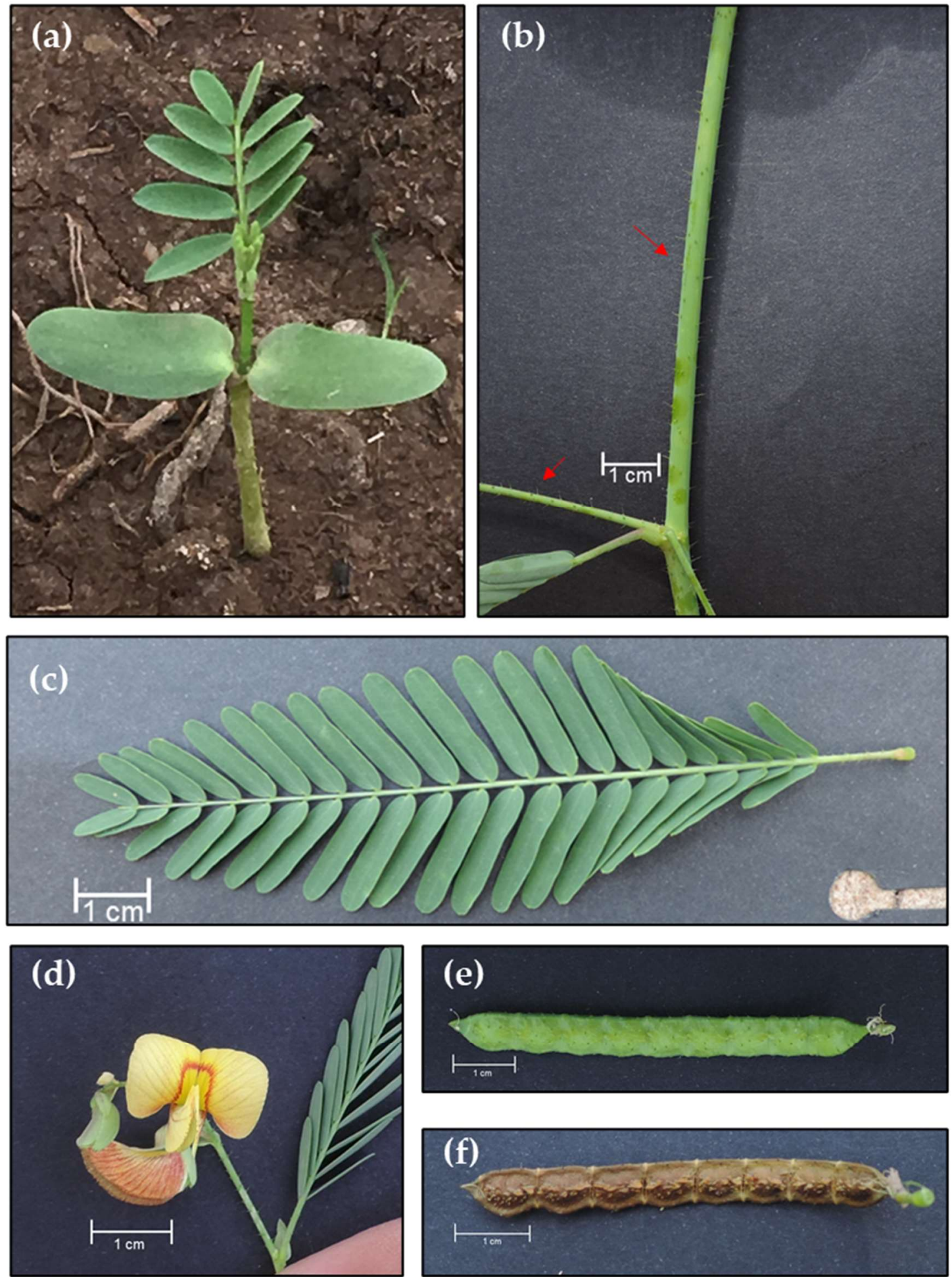

Figure A4. Aeschynomene rudis. (a) Seedling. (b) Branches and stem covered by trichomes. (c) Leaf and leaflets with entire margins. (d) Flower with distinct red trace. (e) Ripening and (f) mature loments and articles. 


\section{References}

1. Rudd, V. The American species of Aeschynomene. Cont. US Natl. Herb. 1955, 32, 1-176.

2. Antunes, L.L.C.; Silva, M.J. Aeschynomene (Leguminosae, Papilionoideae) no estado de Goiás, Brasil. Rodriguésia 2018, 69, 2163-2207. [CrossRef]

3. Hartmann, L.S.; Rodrigues, R.S.; Flores, A.S. O gênero Aeschynomene (Leguminosae-Papilionoideae) no estado de Roraima, Brasil. Rodriguésia 2019, 70, 1-14. [CrossRef]

4. Oliveira, M.L.A.A. Sinopse taxonômica do gênero Aeschynomene L. (Leguminosae-Faboidae) no Rio Grande do Sul, Brasil. Inheringia 2002, 57, 279-301.

5. Fruet, B.L.; Merotto, A., Jr.; Ulguim, A.R. Survey on rice weed management and public and private consultant characteristics in Southern Brazil. Weed Tech. 2019, 1, 1-22. [CrossRef]

6. Takanose, Y.; Ishida, S.; Kudo, N.; Kamitani, T. Effects of tillage and irrigation on the occurrence of native wetland species in fallow paddy fields. Paddy Water Environ. 2013, 11, 45-58. [CrossRef]

7. Pei, Q.; Yuanlain, C.; Huanhao, H.; Bo, L. Effect of flooding irrigation and intermittent irrigation patterns on weed community diversity in late rice fields. Trans. Chin. Soc. Agr. Eng. 2015, 31, 115-121.

8. Kissmann, K.G.; Groth, D. Plantas Infestantes e Nocivas, 2nd ed.; BASF: São Paulo, Brazil, 1999; Volume 2, pp. 831-847.

9. Fleck, N.G.; Lazaroto, C.A.; Schaedler, C.E.; Ferreira, F.B. Suscetibilidade de três espécies de angiquinho (Aeschynomene spp.) a herbicidas de utilização em pós-emergência em arroz irrigado. Rev. Bras. Agroc. 2008, 14, 77-86.

10. Dornelles, S.H.B.; Sanchotene, D.M.; Macedo, L.C.P.; Rodrigues, S.N.; Morais, T.B.; Ebling, E.D.; Sherer, M.B. Controle pós-tardio de Aeschynomene denticulata na cultura do arroz. Vivências 2014, 10, 42-49.

11. Galon, L.; Guimarães, S.; Radüz, A.L.; Lima, A.M.; Burg, G.M.; ZAndoná, R.R.; Bastiani, M.O.; Belarmino, J.G.; Perin, G.F. Competitividade relativa de cultivares de arroz irrigado com Aeschynomene denticulata. Bragantia 2015, 74, 67-74. [CrossRef]

12. Moraes, A.; Carvalho, P.C.F.; Anghinoni, I.; Lustosa, S.B.C.; Costa, S.E.V.G.A.; Kunrath, T.R. Integrated crop-livestock systems in the Brazilian subtropics. Europ. J. Agron. 2013, 57, 4-9. [CrossRef]

13. SOSBAI-Sociedade Sul-brasileira de Arroz Irrigado. Adequação da área e sistemas de cultivo. In Arroz Irrigado: Recomendações Técnicas Para o Sul do Brasil, 1st ed.; SOSBAI, Ed.; SOSBAI: Cachoeirinha, Brazil, 2018; pp. 10-15.

14. Sudianto, E.; Beng-Kah, S.; Ting-Xiang, N.; Saldain, N.E.; Scott, R.C.; Burgos, N.R. Clearfield ${ }^{\circledR}$ rice: Its development, success, and key challenges on a global perspective. Crop Prot. 2013, 49, 40-51. [CrossRef]

15. Boletim do Instituto Rio-Grandense do Arroz: Resultados da Lavoura de Arroz-Safra 2019/2020. Available online: https: / /irga.rs.gov.br/upload/arquivos /202008/19144808-boletim-de-resultados-da-lavoura-safra-2019-2020-irga.pdf (accessed on 25 November 2020).

16. Bajwa, A.A. Sustainable weed management in conservation agriculture. Crop Prot. 2014, 65, 105-113. [CrossRef]

17. The International Herbicide-Resistant Weed Database. Available online: www.weedscience.org (accessed on 6 April 2020).

18. Boletim do Instituto Rio-Grandense do Arroz: Evolução da Colheita de Arroz Safra 2018/19. Available online: https://irgaadmin.rs.gov.br/upload/arquivos/201906/07134923-colheita-18-19.pdf (accessed on 6 April 2020).

19. SOSBAI-Sociedade Sul-brasileira de Arroz Irrigado. Plantas Daninhas. In Arroz Irrigado: Recomendações Técnicas Para o Sul do Brasil, 1st ed.; SOSBAI, Ed.; SOSBAI: Cachoeirinha, Brazil, 2018; pp. 108-132.

20. R Core Team. R; A Language and Environment for Statistical Computing; R Foundation for Statistical Computing: Vienna, Austria, 2018. Available online: https:/ / www.R-project.org/ (accessed on 15 February 2021).

21. Griffith, A.B. Secondary seed dispersal in Aeschynomene virginica: Do floating seeds really find a new home? Nat. Areas J. 2014, 34, 488-494. [CrossRef]

22. Andres, A.; Ávila, L.A.; Marchezan, E.; Menezes, V.G. Rotação de culturas e pousio do solo na redução do banco de sementes de arroz vermelho em solo de várzea. Rev. Bras. Agroc. 2001, 7, 85-88.

23. Marchezan, E.; Oliveira, A.P.B.B.; Ávila, L.A.; Bundt, A.L.P. Dinâmica do banco de sementes de arroz-vermelho afetado pelo pisoteio bovino e tempo de pousio da área. Planta Daninha 2003, 21, 55-62. [CrossRef]

24. Oliveira, J.C.S.; Marchezan, E.; Storck, L.; Machado, S.L.O. Sistemas de preparo do solo para o arroz irrigado (Oryza sativa L.). Ciênc. Rural 1994, 24, 189-193. [CrossRef]

25. Cruscicol, C.A.C.; Lima, E.V.; Andreotti, M.; Schiocchet, M.A. Aplicação tardia de glyphosate e estande e desenvolvimento inicial o arroz em sistema de cultivo mínimo. Planta Daninha 2002, 20, 45-51. [CrossRef]

26. Marchezan, E.; Garcia, G.A.; Camargo, E.R.; Massoni, P.F.S.; Arosemena, D.R.; Oliveira, A.P.B.B. Manejo da irrigação em cultivares de arroz no Sistema pré-germinado. Ciênc. Rural. 2007, 37, 45-50. [CrossRef]

27. Villa, S.C.C.; Marchezan, E.; Ávila, L.A.; Massoni, P.F.S.; Teló, G.M.; Machado, S.L.O.; Camargo, E.R. Arroz tolerante a imidazolinonas: Controle do arroz-vermelho, fluxo gênico e efeito residual do herbicida em culturas sucessoras não-tolerantes. Planta Daninha 2006, 24, 761-768. [CrossRef]

28. Santos, F.M.; Marchezan, E.; Machado, S.L.O.; Villa, S.C.C.; Ávila, L.A.; Massoni, P.F.S. Controle químico de arroz-vermelho na cultura do arroz-irrigado. Planta Daninha 2007, 25, 405-412. [CrossRef]

29. Menezes, V.G.; Mariot, C.H.P.; Kalsing, A.; Goulart, I.C.G.R. Arroz-vermelho (Oryza sativa) resistente aos herbicidas imidazolinonas. Planta Daninha 2009, 27, 1047-1052. [CrossRef]

30. Bonow, J.F.L.; Lamego, F.P.; Andres, A.; Ávila, L.A.; Teló, G.M.; Egewarth, K. Resistance of Echinochloa crus-galli var. mitis to imazapyr + imazapic herbicide and alternative control in irrigated rice. Planta Daninha 2018, 36, 1-11. [CrossRef] 
31. Counce, P.A.; Keisling, T.C.; Mitchell, A.J. A Uniform, Objective, and Adaptive System for Expressing Rice Development. Crop Sci. 2000, 40, 436-443. [CrossRef]

32. Beckie, H.J.; Reboud, X. Selecting for weed resistance: Herbicide rotation and mixture. Weed Tech. 2009, 23, 363-370. [CrossRef]

33. Beckie, H.J.; Harker, K.N. Our top 10 herbicide-resistant weed management practices. Pest Man. Sci. 2017, 73, 1045-1052. [CrossRef]

34. Theisen, G.; Silva, J.J.C.; Silva, J.S.; Andres, A.; Anten, N.P.R.; Bastiaans, L. The birth of a new cropping system: Towards sustainability in the sub-tropical lowland agriculture. Field Crop Res. 2017, 252, 82-94. [CrossRef]

35. Andres, A.; Concenço, G.; Theisen, G.; Vidotto, F.; Ferrero, A. Selectivity and weed control efficacy of pre- and post-emergence applications of clomazone in Southern Brazil. Crop Prot. 2013, 53, 103-108. [CrossRef]

36. Levy, R.J.; Bond, J.A.; Webster, E.P.; Griffin, J.L.; Linscombe, S.D. Effect of cultural practices on weed control and crop response in imidazolinone-tolerant rice. Weed Tech. 2006, 20, 249-254. [CrossRef]

37. Webster, E.P.; Carlson, T.P.; Salassi, M.E.; Hensley, J.B.; Blouin, D.C. Imazethapyr plus residual herbicide programs for imidazolinone-resistant rice. Weed Tech. 2012, 26, 410-416. [CrossRef]

38. Ahmed, S.; Chauhan, B.S. Efficacy and phytotoxicity of different rates of oxadiargyl and pendimethalin in dry-seeded rice (Oryza sativa L.) in Bangladesh. Crop Prot. 2015, 72, 169-174. [CrossRef]

39. Concenço, G.; Andres, A.; Schreiber, F.; Moisinho, I.S.; Martins, M.B. Control of jointvetch (Aeschynomene spp.), establishment and productivity of rice as a function of [imazapyr + imazapic] doses. J. Agr. Sci. 2018, 10, 287-296. [CrossRef]

40. Ruiz-Santaella, J.P.; Heredia, A.; De Prado, R. Basis of selectivity of cyhalofop-butyl in Oryza sativa L. Planta 2006, 223, 191-199. [CrossRef] [PubMed]

41. Grossmann, K. Quinclorac belongs to a new class of highly selective auxin herbicides. Weed Sci. 1998, 46, 707-716. [CrossRef]

42. Agostinetto, D.; Dal Magro, T.; Vargas, L.; Noldin, J.A. Resistência de Cyperus difformis L. ao herbicida pyrazosulfuron-ethyl e alternativas de controle. Ciênc. Agr. 2011, 32, 839-848. [CrossRef]

43. Oliveira, M.L.A.A. Aeschynomene indica L. no Brasil: Primeira citação. Inheringia 2001, 41, 3-8.

44. Begum, M.; Juraimi, A.S.; Amartalingam, R.; Man, A.B.; Rastans, S.O.B.S. The effects of sowing depth and flooding on the emergence, survival, and growth of Fimbristylis miliaceae (L.) Vahl. Weed Biol. Man 2006, 6, 157-164. [CrossRef]

45. Chauhan, B.S.; Johnson, D.E. Ludwigia hyssopifolia emergence and growth as affected by light, burial depth and water management. Crop Prot. 2009, 28, 887-890. [CrossRef]

46. Abou El-Darag, I.H.A.; Abd El-Naby, S.S.M.; El-Ghandor, A.M.A. Effect of water regime and weed control treatments on weeds, growth and yields in hybrid rice. J. Plant Prod. 2017, 8, 939-943. [CrossRef]

47. Karim, R.S.M.; Man, A.B.; Sahid, I.B. Weed problems and theis management in rice fields of Malaysia: An overview. Weed Biol. Man 2004, 4, 177-186. [CrossRef]

48. Owen, M.D.K.; Zelaya, I.A. Herbicide-resistant crops and weed resistance to herbicides. Pest Man Sci. 2005, 61, 301-311. [CrossRef] [PubMed]

49. Kumar, V.; Singh, S.; Chhokar, R.S.; Malik, R.K.; Brainard, D.C.; Ladha, J.K. Weed management strategies to reduce herbicide use in zero-till rice-wheat cropping systems of the Indo-Gangetic Plains. Weed Tech. 2013, 27, 241-254. [CrossRef]

50. Giraud, E.; Hannibal, L.; Fardoux, J.; Verméglio, A.; Dreyfus, B. Effect of Bradyrhizobium photosynthesis on stem nodulation of Aeschynomene sensitiva. Proc. Natl. Acad. Sci. USA 2000, 97, 14795-14800. [CrossRef] [PubMed] 